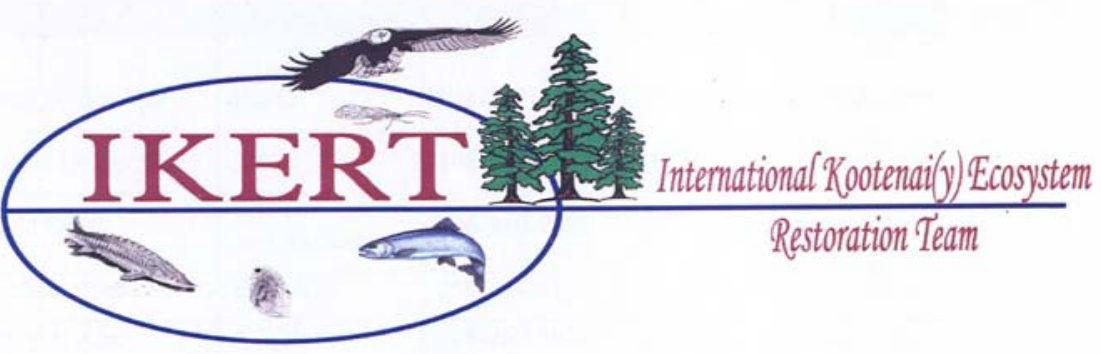

\title{
Kootenai River Nutrient Dosing System and N-P Consumption: Year 2008
}

For:

Kootenai Tribe of Idaho

P.O. Box 1269

Bonners Ferry

Idaho 83805

U.S.A.

By:

Ward \& Associates Ltd 307-977 Mainland Street

Vancouver, B.C.

Canada V6B 1T2

In co-operation with IKERT

January 2009

BPA Project 199404900

Contract \# 39133 


\section{Kootenai River Nutrient Dosing System and N-P Consumption Year 2008}

1. Introduction

2. Diaphragm Pump Dosing System

3. Flow Measurements at USGS Kootenai River Leonia Gauge

4. Measurements of Samples of 10-34-0 Nutrient

5. Turbidity Monitoring and Start-up Date

6. Operation and Performance of Dosing \& Measuring System

7. Nitrogen Concentration \& N-P Uptake

Appendices:

A. Manufacturer's Data Sheet for 10-34-0 Liquid Nutrient

B. Monthly DMR (Discharge Monitoring Report) Sheets \& Key Pages from EPA Permit

Figures

1. Gamma/L Pump(s), as installed at the Leonia site

2. Solar photovoltaic panels for operating Gamma dosing pumps, and for powering Seametrics flow meter.

3. Rating curve for Kootenai River at Leonia, Station Number 12305000

4. Kootenai Hydrograph for recent summer seasons at USGS Gauge at Leonia.

5. Hydrograph for Kootenai River at Leonia for Period $26^{\text {th }} \mathrm{July}$ to $29^{\text {th }} \mathrm{July}$ ' 08 , associated with an emergency shut-down of turbines

6. Secchi Disk measurement at Leonia in mid June 2008

7. Secchi Disk Depth Measurements for Kootenai River at KTI Headquarters

8. Relative light intensity and relative growth rates at the river bed

9. Start of season dosing system set-up

10. Flow calibration and checking of Seametrics flow instrument

11. Comparison of volume of 10-34-0 added versus volume needed based on automated river gauge readings.

12. Weekly nitrogen $\left(\mathrm{NO}_{3}+\mathrm{NO}_{2}\right)$ concentrations for the summer 2008 period versus distance downstream from nutrient addition site.

13. Nitrogen and phosphorus uptake computations in first $8 \mathrm{~km}$ of treatment reach, Kootenai River, ID.

14. Phosphorus uptake estimates based on nitrogen losses in first $8 \mathrm{~km}$ of treatment reach, Kootenai River, ID.

Tables:

1. Peak River Flow Rates for Dosing from System Installed

2. Density measurements of consignments of 10-34-0 nutrient solution

3. Analytical laboratory results for P concentration in samples of 10-34-0 liquid nutrient

4. Relative growth rates for three values of Secchi Depth at three river flows

5. Summary of Nutrient (10-34-0) Addition Program for 2008 and 2007 Seasons. 


\section{Introduction}

In early 2006 we designed and built low energy consumption, pump-operated system, for dosing of the liquid nutrient in the summer 2006 season. This operated successfully, and the system was used again during the 2007 and 2008 seasons for dosing.

During the early winter period, 2008, laboratory tests were made of the liquid nutrient pump system, and it was noted that small amounts of air were being entrained on the suction side of the pump, during conditions when the inlet pressure was low. It was believed that this was the cause of diurnal fluctuations in the flow supplied, characteristic of the 2007 year flow data. Replacement of "0" rings on the inlet side of the pumps was the solution to this problem, and when tested in the field during the summer season, the flow supplied was found to be stable.

A decision was made by the IKERT committee at the meeting of $20^{\text {th }}$ to $21^{\text {st }}$ May 2008 (held in Coeur d'Alene, Idaho) to use an injection flow rate of liquid fertilizer (polyammonium phosphate 10-34-0) to achieve a target phosphorus concentration of 3.0 $\mu \mathrm{g} / \mathrm{L}$, after complete mixing in the river. This target concentration was the same as that used in 2006 and 2007. The proposed starting date was as early as possible in June 2008.

Plans were made to measure the dosing flow in three ways. Two of the three methods of flow measurement ( 1 and 2 below) are inter-dependent. These were:

1. Direct measurement of flow rate by diverting dosing flow into a $1000 \mathrm{~mL}$ volume standard flask. The flow rate was computed by dividing the flask volume by the time required to fill the flask. This was done a few times only during the summer period.

2. Adjusting the flow rate reading of the Gamma dosing pump using the "calibration" function to achieve agreement with the flow rate computed by method 1 above.

3. Direct measurement by electrical signal from conductive fluid passing through a magnetic field (Seametrics meter, as used in previous years). Values were recorded every 4 minutes by a data-logger. This instrument has been shown to be reliable, and in agreement with method 1 to within the expected uncertainty (within 2\%).

Liquid nutrients were delivered to the site in late May, and system testing was done the same day. High concentrations of suspended sediment in the water column, as indicated by shallow Secchi depth readings, were present in the river in the last part of May, into June. A plan was made to delay the start up of nutrient addition to a date later than $1^{\text {st }}$ June, because the aquatic productivity was almost certainly to be compromised by insufficient light availability. Daily monitoring of Secchi depths was done, showing declining turbidity in early June. A decision was made to start the system on $15^{\text {th }}$ June, by which time conditions were good. 


\section{Diaphragm Pump Dosing System}

The system used in 2008 was the same as employed the previous two years. Very low energy consumption pumps were used. These were small, solenoid operated diaphragm pumps, running on a maximum power demand of $23 \mathrm{~W}$, manufactured by ProMinent Dosiertechnik GmbH. The requirements at the Leonia site were such that two of the largest pumps in the Gamma/L model family (model GALA0232) were needed in order to supply a sufficient flow rate for dosing the Kootenai River at expected summer peak flows. With modest backpressure on the pumps, each was capable of supplying 30 to 34 L/hour of nutrient. Two pumps in parallel were therefore capable of supplying 60 to 68 L/hour. Repeatability of the metering flow from manufacturer's specifications was $\pm 2 \%$. The pump had capability to read the dosed flow rate in L/hour, but the correct read out value had to be set periodically by independent volumetric flow measurement, e.g. with a standard flask.

Flow rates supplied by the Gamma/L pump (see Figure 1) were adjustable either by changing the stroking speed (frequency per minute, up to $180 /$ minute maximum), or by changing the length of stroke (measured as a $\%$ of the full stroke distance). For the 2008 season, the length of stroke was set at the beginning of the season to $100 \%$, and was left at that value for the rest of the season. Daily adjustments, as needed, of the dosed flow were then made by adjusting the stroking frequency.

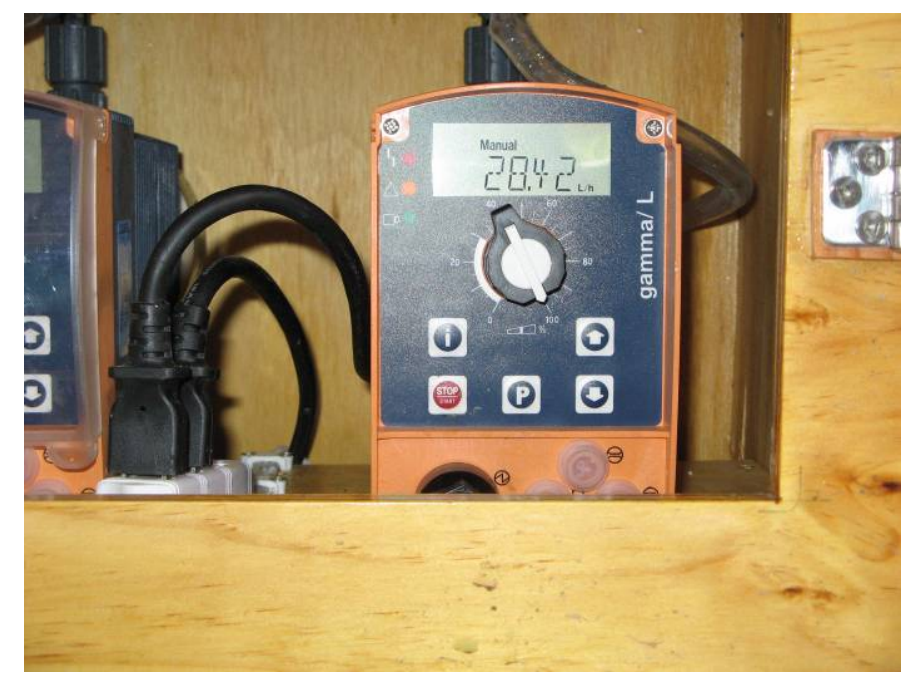

Figure 1. Gamma/L Pump(s), as installed at the Leonia site

For sites downstream of the dosing location, where mixing of the nutrient stream has been completed across the width (and depth) of the river, there is a relationship between the flow rate of dosing, the flow rate of the river, and the desired concentration of nutrient (phosphorus $\mathrm{P}$ ) in the river. For 10-34-0, with the maximum dosing rate at $32 \mathrm{~L} /$ hour for one pump in use, and $64 \mathrm{~L} /$ hour for two pumps in use, the maximum river flow rate that may be treated is as shown in Table 1. 
Table 1. Peak River Flow Rates for Dosing from System Installed

\begin{tabular}{|l|c|c|}
\hline \multirow{2}{*}{} & \multicolumn{2}{|c|}{$\begin{array}{c}\text { Target concentration of nutrient P after } \\
\text { completion of mixing in the river: 3 } \mu \mathrm{g} / \mathrm{L}\end{array}$} \\
\cline { 2 - 3 } & One Pump & Two Pumps \\
\hline $\begin{array}{l}\text { Maximum River Flow for } \\
\text { System Installed } \mathrm{m}^{3} / \mathrm{s}\end{array}$ & 620 & 1240 \\
\hline $\begin{array}{l}\text { Maximum River Flow for } \\
\text { System Installed cfs }\end{array}$ & 21,900 & 43,800 \\
\hline
\end{tabular}

For the 2008 season, the river flows exceeded the capacity of one pump for a short period after start-up in mid-June, so two pumps were used during this time to provide sufficient nutrient flow rate. For the rest of the season (until the $30^{\text {th }}$ September shut-down) one pump was sufficient for operation.

For the power requirements of the solar powered system, it was important that there was sufficient battery capacity to run the system through several successive days of cloudy weather. Additionally it was important that the photovoltaic solar panels were sufficiently large to supply electricity to keep up with the average power demand from the pump(s).

For a duty cycle of $5 \frac{1}{2}$ hours of bright sunshine per 24 hours, for a pump draw of 2.9 amps (one pump at full speed and one pump at reduced speed), and for an efficiency of 0.85 , the electric current that must be supplied from the solar array in bright sunshine is:

$$
\text { Maximum current to be supplied : } \quad 2.9 * 24 / 5 \frac{1 / 2}{2} \quad 1 / 0.85=14.9 \text { amps }
$$

The solar system for nutrient pumping used for the 2006 and 2007 seasons was adequate, and was used again for 2008. The two photovoltaic panels (Kyocera KC130 watt modules) were supported on a wooden rack, whose angle could be adjusted so that the panels were perpendicular to the sun at the zenith, see Figure 2. The panels were connected in parallel, so that a maximum current close to the target amount of 14.9 amps was supplied in full sunshine. A 50 foot $(15 \mathrm{~m})$ length of 2 conductor, heavy duty (10 gauge) copper wire was used to connect the panels to the controller in the battery box.

In 2008, a decision was made to upgrade the solar panel used for powering the Seametrics meter system to a (single) Kyocera 130 watt maximum power output panel, similar to those used for powering the nutrient pumps, see Figure 2. 


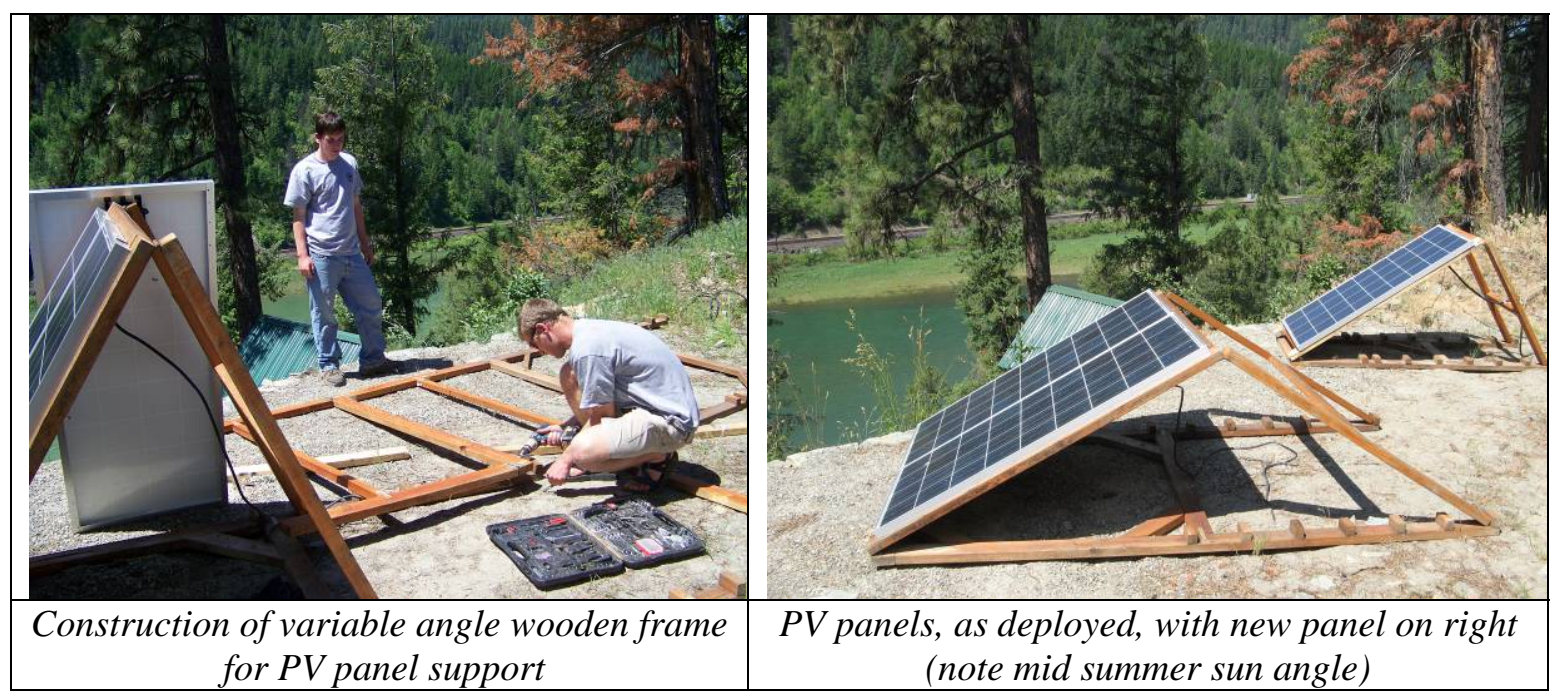

Figure 2. Solar photovoltaic panels for operating Gamma dosing pumps, and for powering Seametrics flow meter (new PV panel for 2008).

\section{Flow Measurements at USGS Kootenai River Leonia Gauge}

Flow measurements at the Leonia gauging station (USGS station \# 12305000) are dependent on the rating curve for this river location. Because of the confluence of Boulder Creek only $0.9 \mathrm{~km}$ downstream of the water level gauge, the measurements recorded depend on the extent of intrusion of the Boulder Creek delta into the channel of the Kootenai River. Periodic events, such as large floods in the Kootenai River, cause mobilization of the delta materials, and cause significant changes in the rating curve at the gauge. For the 2008 season, a rating curve (USGS Curve \# 25) that had been updated on $24^{\text {th }}$ February 2007 was used. 


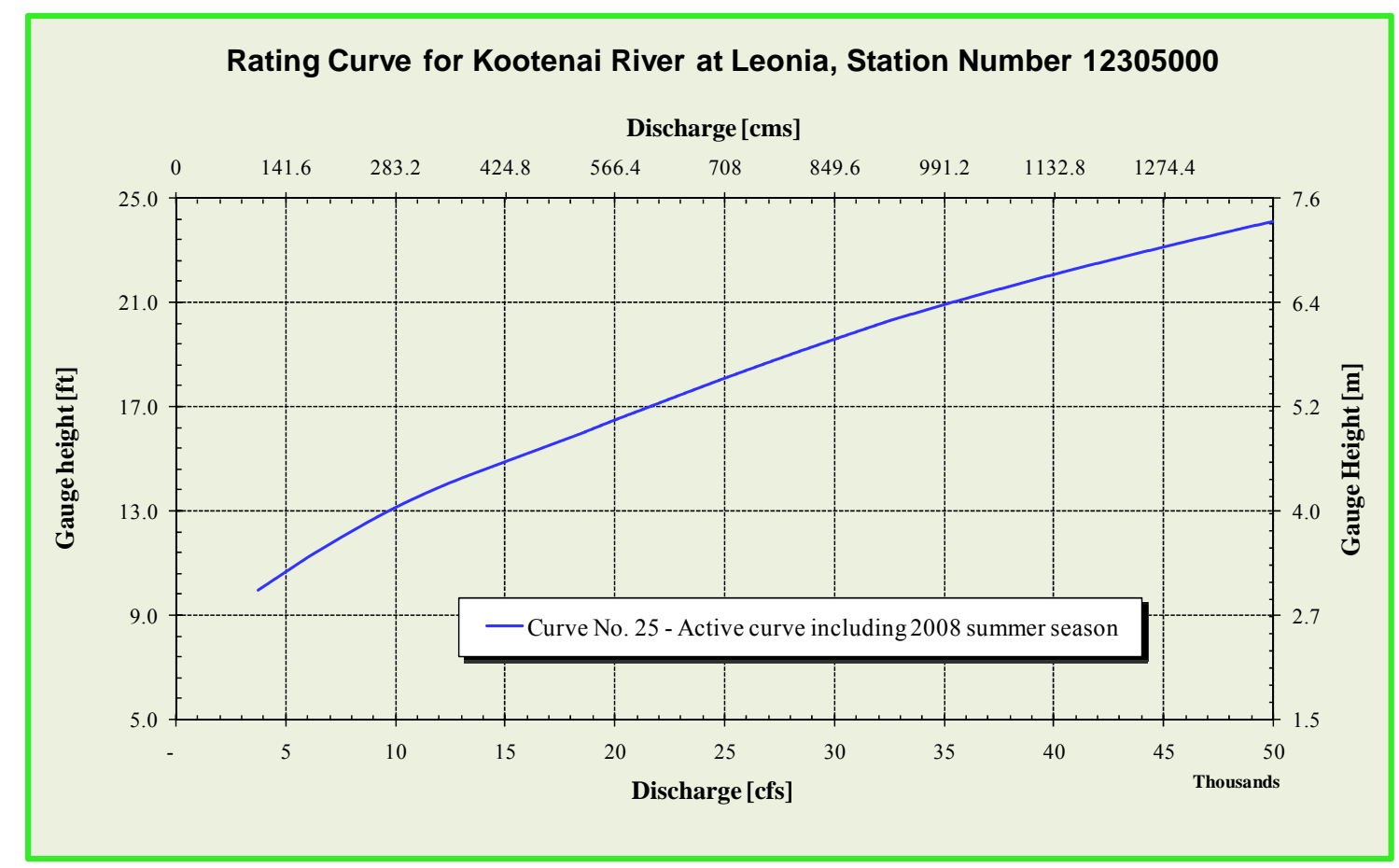

Figure 3: Rating curve for Kootenai River at Leonia, Station Number 12305000

On the basis of uncertainties expected at most USGS stations, we believe that the uncertainty for flows obtained with this rating curve is about $\pm 5 \%$. Calculations of the amount of liquid nutrient required to achieve a target concentration of $\mathrm{P}$ in the downstream river, which are based on knowledge of the river flow, carry an uncertainty that includes this, plus uncertainties associated with the concentration of product supplied by the manufacturer, and the uncertainty of the flow delivered by the nutrient pump.

Flows for the period $1^{\text {st }}$ May to $30^{\text {th }}$ September 2008 are shown, together with flows in the previous three summer seasons, see Figure 4. Note that the flows for about the first two weeks of operation, from start-up until end of June 2008 were large enough to require both Gamma/L pumps working in parallel, and after this period one pump was sufficient. The gradual tapering of flows during the June to September period, associated with systematic reductions in turbine flows, provides a more natural hydrograph than that produced by turbine operations in 2007. 


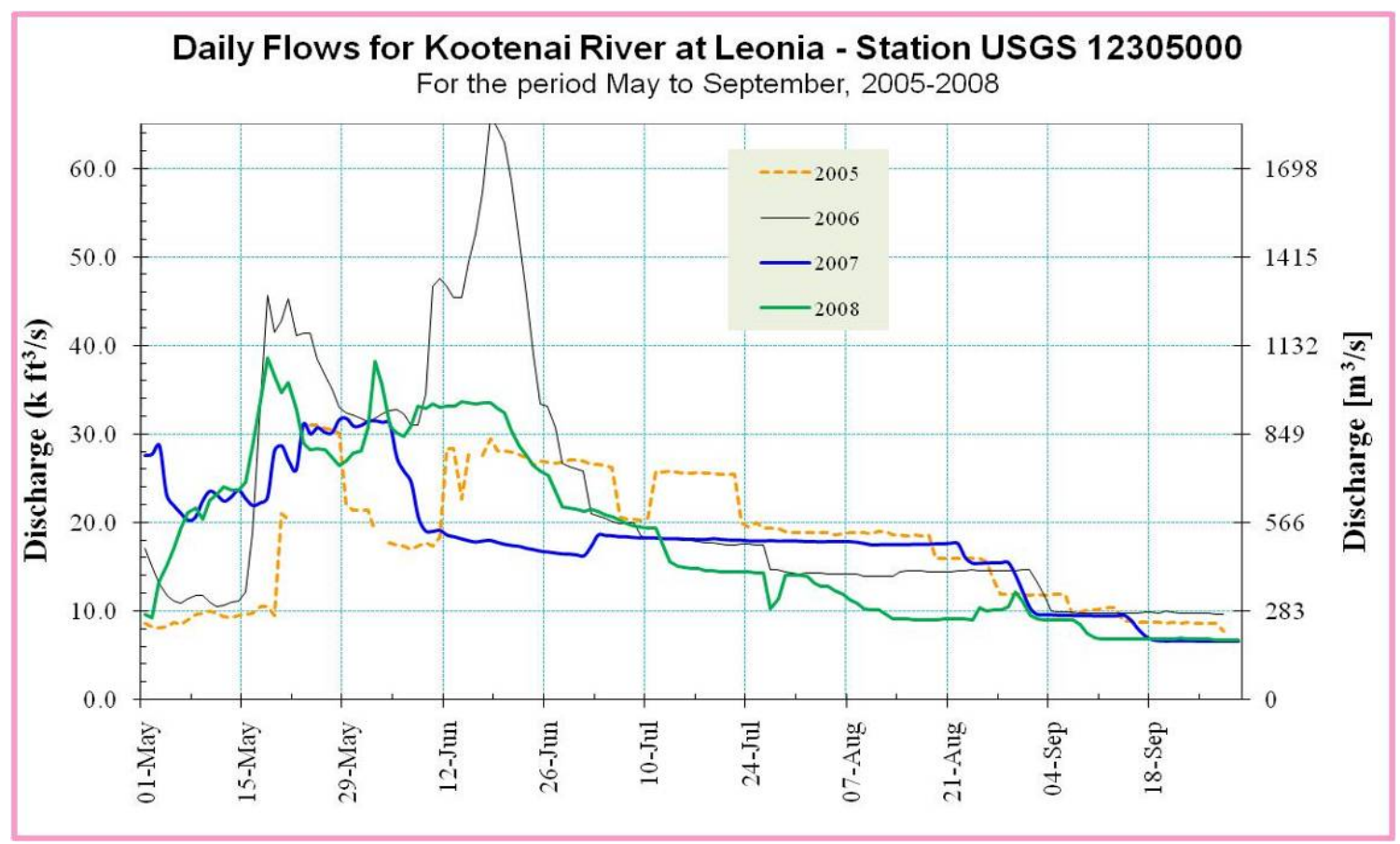

Figure 4. Kootenai Hydrograph for recent summer seasons at USGS Gauge at Leonia.

The major drop in flow during the period $27^{\text {th }}$ to $28^{\text {th }}$ July, see Figure 5, was due to an emergency, resulting from a fatality of a person downstream of Libby Dam. Turbine flows were very much reduced for a 24 hour period. 


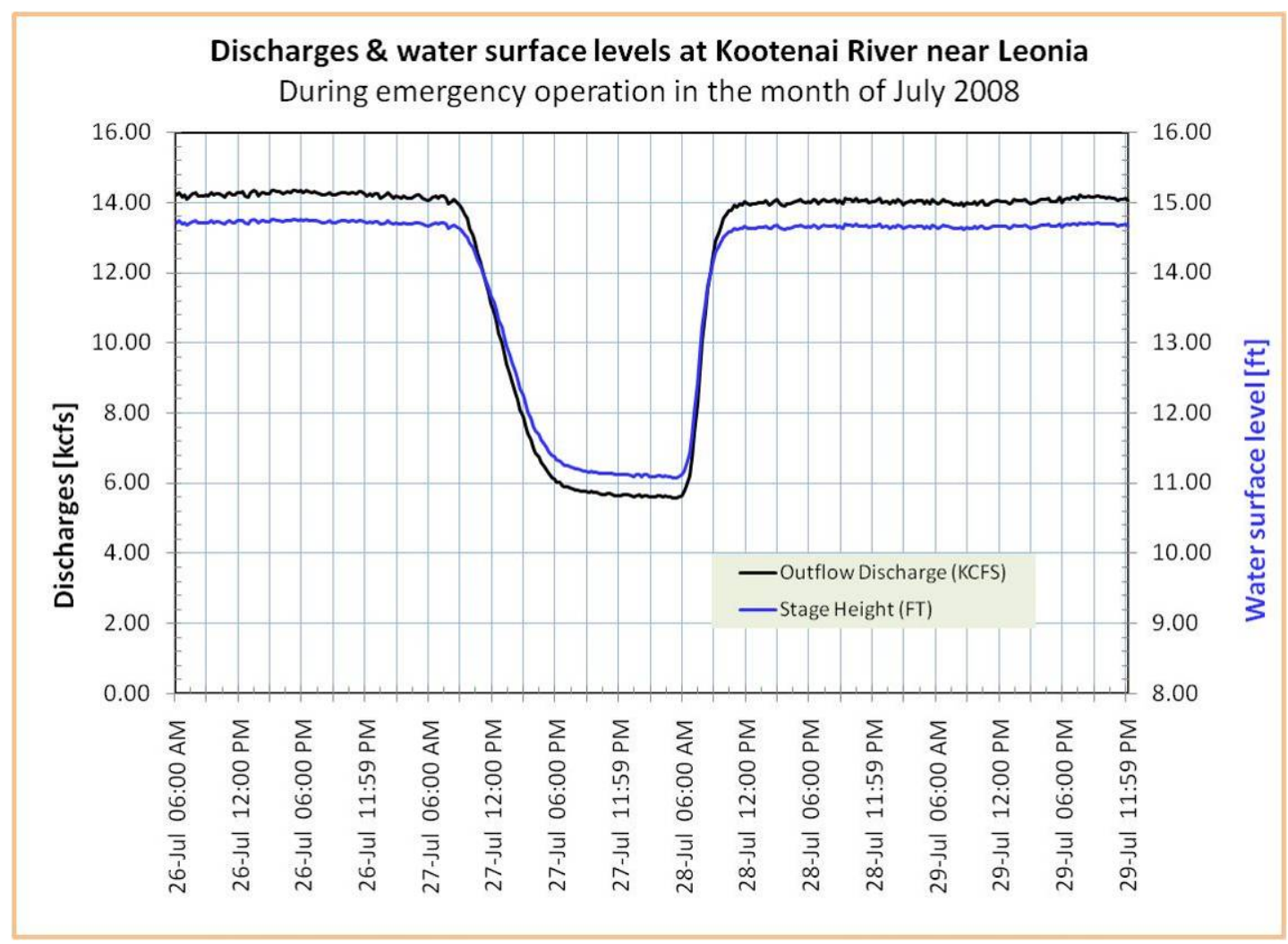

Figure 5. Hydrograph for Kootenai River at Leonia for Period $26^{\text {th }} \mathrm{July}^{\text {to }} 29^{\text {th }} \mathrm{July}^{\mathrm{a}}$ 2008, associated with an emergency shut-down of turbines

\section{Analytical Measurements of Samples of 10-34-0 Nutrient}

Two procedures were used to check on the concentration of dissolved solids in the 10-34-0 product supplied.

One was to take samples and send away for analysis, which typically took 1-2 weeks for receipt of a report from the laboratory. Dilutions were required as part of the analytical procedure.

The other procedure was to make an instant assessment of the dissolved solids concentration in the 10-34-0, by weighing an exact volume contained in a $25 \mathrm{~mL}$ density bottle. This was done on six occasions during the season, see Table 2 . The temperature range for the samples was 20 to $27^{\circ} \mathrm{C}$. Results showed very good consistency of density of the product (within $\pm 1 \%$ ). Additionally there was good agreement between the manufacturer's spec sheet value (specific gravity 1.398) and the average of the measured values. This did not confirm concentrations of individual chemical components, but gave assurance that there was a likelihood that the product was as promised by the manufacturer's spec sheet. 
Table 2. Density measurements of consignments of 10-34-0 nutrient solution

\begin{tabular}{|l|l|l|l|l|}
\hline $\begin{array}{l}\text { Date } \\
\text { measured } \\
2008\end{array}$ & $\begin{array}{l}\text { Weight } \\
\text { gram }\end{array}$ & $\begin{array}{l}\text { Volume } \\
\mathrm{mL}\end{array}$ & $\begin{array}{l}\text { Density } \\
\mathrm{g} / \mathrm{mL}\end{array}$ & Comments \\
\hline $19^{\text {th }}$ June & 35.329 & 25.00 & 1.413 & Fresh from delivery truck \\
\hline $25^{\text {th }}$ June & 34.990 & 25.00 & 1.399 & From tanks \\
\hline $4^{\text {th }}$ Aug & 34.900 & 25.00 & 1.396 & From tanks \\
\hline $11^{\text {th }}$ Aug & 34.868 & 25.00 & 1.395 & \\
\hline $18^{\text {th }}$ Aug & 34.823 & 25.00 & 1.393 & \\
\hline $27^{\text {th }}$ Aug & 35.088 & 25.00 & 1.404 & Fresh from delivery truck \\
\hline & & & & \\
\hline Mean & & & 1.400 & \\
\hline
\end{tabular}

On the basis of the manufacturer's specification (see data sheet, Appendix A), the $\mathrm{P}_{2} \mathrm{O}_{5}$ content of the 10-34-0 is $3.95 \mathrm{lbs} /$ gallon, which reduces to a $\mathrm{P}$ content of :

$3.964 / 2.29=1.731 \mathrm{lbs} /$ gallon.

The metric units values are as follows:

Total-P

TDP (total dissolved phosphorus)

SRP (soluble reactive phosphorus)
$207.8 \mathrm{~g} / \mathrm{L}$

$207.8 \mathrm{~g} / \mathrm{L}$

$63.8 \mathrm{~g} / \mathrm{L}$

A check was made on the phosphorus content of 10-34-0 samples that were delivered to the site on various dates during the season. Typically the nutrient was delivered by a tandem truck, with two tanks. The concentration of phosphorus was measured by taking one sample from each tank, and sending it away for analysis. Samples were collected on two delivery dates during the summer season. Three measurements were made on each sample, as follows:

- Total-P

- TDP (total dissolved phosphorus)

- SRP (soluble reactive phosphorus)

Results of the analysis are shown, see Table 3.

The average value of the total $\mathrm{P}$ concentrations for the samples sent to the lab was $188,200 \mathrm{mg} / \mathrm{L}$. This is significantly lower (by $9.5 \%$ ) than the value in the manufacturers spec sheet.

Reasons for the discrepancy are unknown, but there may be issues with the ability of the laboratory to measure satisfactorily very large concentrations of nutrients. The fact that 
the specific gravity of the 10-34-0 was measured as being correct, supports the idea that the product likely contained the correct concentration of chemicals.

Table 3. Analytical laboratory results for $\mathrm{P}$ concentration in samples of 10-34-0 liquid nutrient

\begin{tabular}{|c|c|c|c|c|c|}
\hline \multicolumn{6}{|c|}{ Phosphorus concentration based on lab results for each batch of nutrient delivery } \\
\hline SAMPLE ID & $\begin{array}{c}\text { TOTAL-P } \\
(\mathrm{mg} / \mathrm{L})\end{array}$ & $\begin{array}{l}\text { TDP } \\
(\mathrm{mg} / \mathrm{L})\end{array}$ & $\begin{array}{c}\text { SRP } \\
(\mathrm{mg} / \mathrm{lL})\end{array}$ & $\begin{array}{l}\text { SRP } \\
\text { to TP } \\
\left(\frac{\circ}{0}\right)\end{array}$ & $\begin{array}{c}\text { SRP } \\
\text { to TDP } \\
\left(\frac{\circ}{\circ}\right)\end{array}$ \\
\hline $\begin{array}{cc}\text { 14-Jun-08 } & \text { Sample 1 - Tank 1 } \\
& \text { Sample 1 - Tank 2 } \\
& \text { Average of the two : } \\
& \text { Difference from published value: } \\
\text { Difference between the two batches: }\end{array}$ & $\begin{array}{l}191,100 \\
191,200 \\
191,150 \\
-10 \% \\
0 \% \\
\end{array}$ & $\begin{array}{l}183,300 \\
189,300 \\
186,300 \\
-12 \%\end{array}$ & $\begin{array}{l}61,900 \\
59,500\end{array}$ & $\begin{array}{l}32 \% \\
31 \%\end{array}$ & $\begin{array}{l}34 \% \\
31 \%\end{array}$ \\
\hline $\begin{array}{cc}\text { 8-Jul-08 } & \text { Sample 1 - Tank 1 } \\
& \text { Sample 1 - Tank 2 } \\
& \text { Average of the two : } \\
& \text { Difference from published value: } \\
\text { Difference between the two batches: }\end{array}$ & $\begin{array}{l}178,500 \\
191,900 \\
185,200 \\
-13 \% \\
-8 \% \\
\end{array}$ & $\begin{array}{l}174,300 \\
191,300 \\
182,800 \\
-14 \%\end{array}$ & $\begin{array}{l}77,800 \\
81,600\end{array}$ & $\begin{array}{l}44 \% \\
43 \%\end{array}$ & $\begin{array}{l}45 \% \\
43 \%\end{array}$ \\
\hline $\begin{array}{l}\text { Average of all samples } \\
\text { Difference from published value: }\end{array}$ & $\begin{array}{l}188,175 \\
-11 \%\end{array}$ & $\begin{array}{l}184,550 \\
-13 \%\end{array}$ & & $37 \%$ & $38 \%$ \\
\hline Published values: & 212,470 & 212,470 & & $30 \%$ & $30 \%$ \\
\hline
\end{tabular}

\section{Turbidity Monitoring and Start-up Date.}

Turbidity measurements were high in the river prior to the scheduled start-up date on $1^{\text {st }}$ June. There was concern that aquatic productivity would be reduced, because of low light penetration in the water column. The origin of the turbidity was tributary rivers (likely the Fisher River) that enter the Kootenai river downstream of Libby Dam. Secchi disk measurements for the river at the KTI headquarters were commenced on the $22^{\text {nd }}$ of May, with occasional checks on turbidity at the Leonia site, see Figure 6. There was a systematic decrease in turbidity in the river for several weeks during the late May to July period, as indicated by increasing Secchi disk depths, see Figure 7.

At the scheduled date for start-up, $1^{\text {st }}$ June, the Secchi depths, in the range 0.9 to $0.6 \mathrm{~m}$, were judged to be too shallow for adequate primary productivity on the river substrate. 


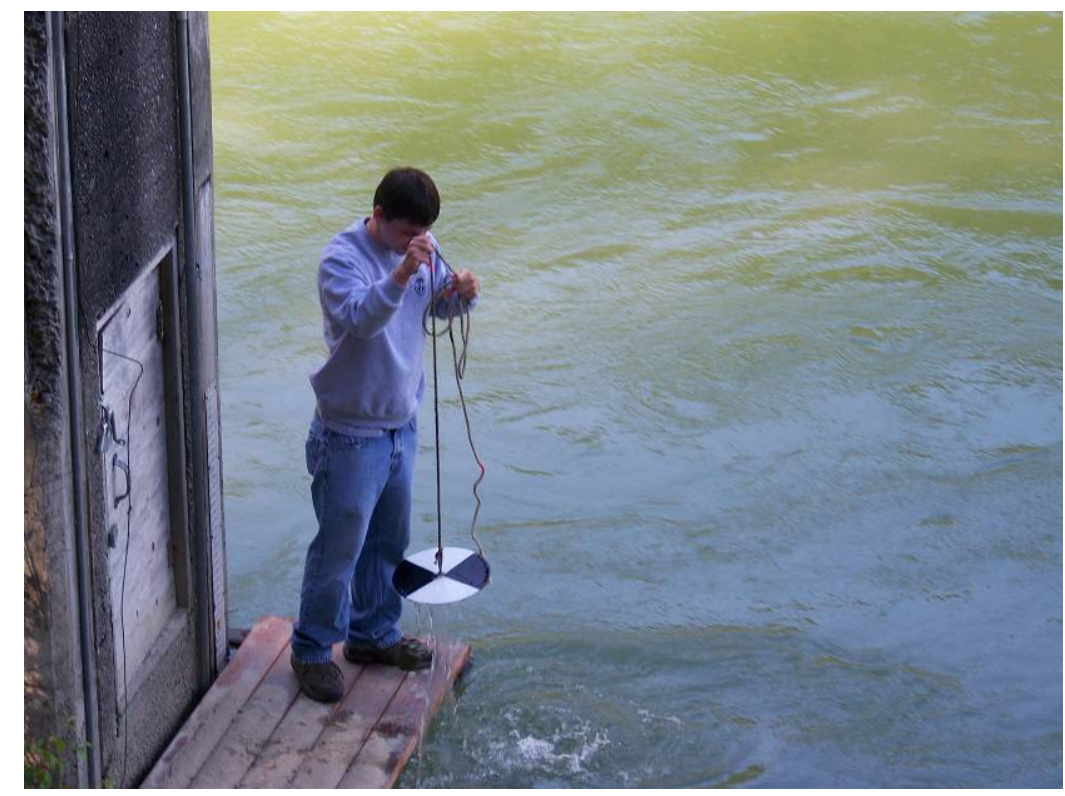

Figure 6. Secchi Disk measurement at Leonia in mid June 2008

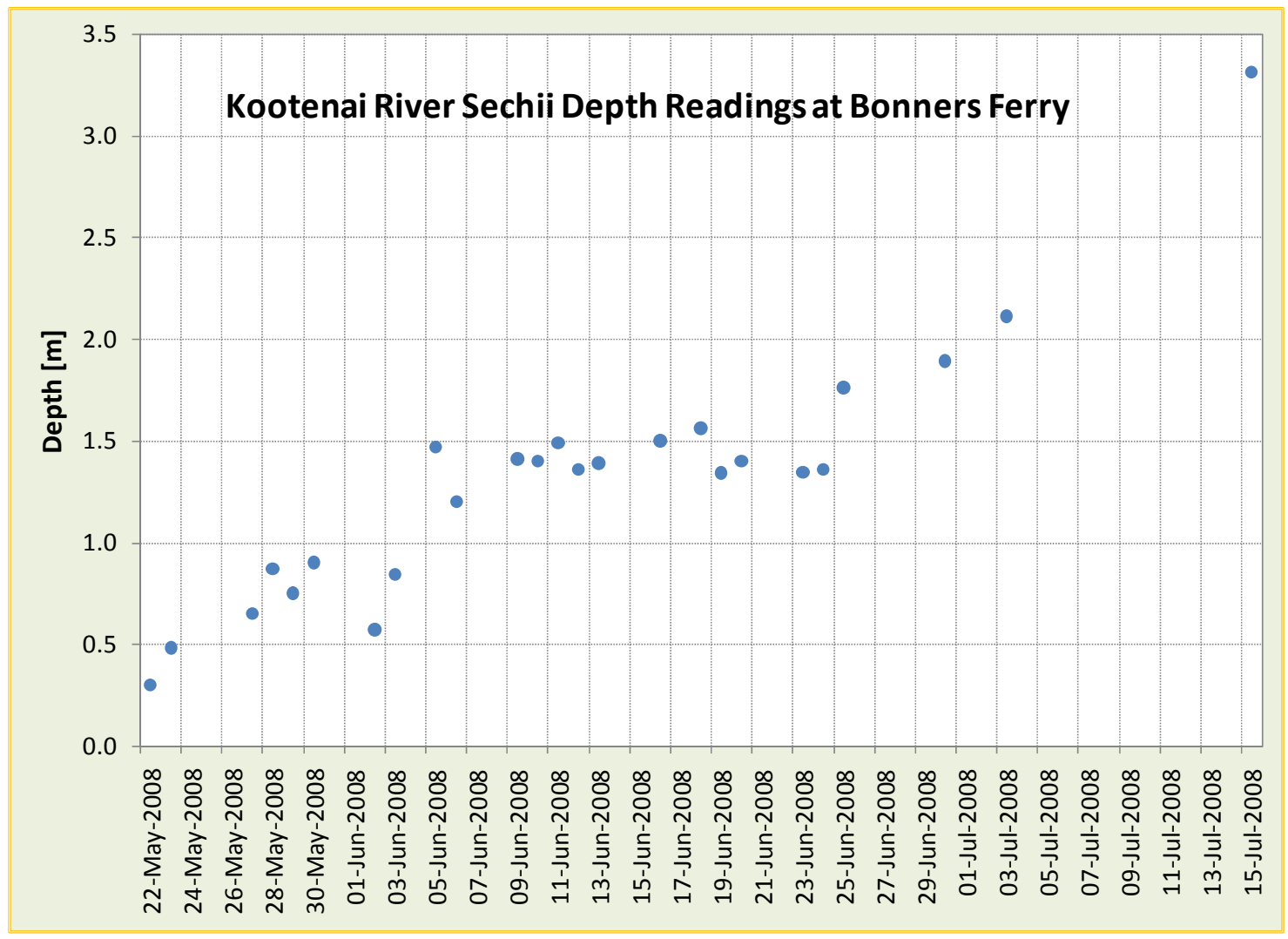

Figure 7. Secchi Disk Depth Measurements for Kootenai River at KTI Headquarters 
A calculation procedure that was developed in 2006 was used again, with modifications in 2008, to help decide at what point the water column, particularly the bed of the river, would be productive. The procedure uses knowledge of the cross-sectional shape, specifically the depth at various points across the channel width, to estimate ambient light penetration and the likelihood of stimulating growth on the bed of the channel. This is done for several cross-sections for a $9 \mathrm{~km}$ reach of the river downstream of the dosing point. The growth rate formula is an exponential reduction with increasing depth, and is an estimate only. It is related to the Secchi depth. Two formulae (see Figure 8) apply, as follows:

Light reduction: $\quad \mathrm{I}_{\mathrm{o}} / \mathrm{I}_{\mathrm{d}}=\exp -\left(1.7 / \mathrm{z}_{\mathrm{sd}}\right) \mathrm{d}$

Growth rate reduction: $\quad \mathrm{G}_{\mathrm{o}} / \mathrm{G}_{\mathrm{d}}=\exp -\left(0.34 / \mathrm{z}_{\mathrm{sd}}\right) \mathrm{d}$

Subscript o denotes conditions on the surface, and subscript d denotes conditions at submergence depth $d . z_{s d}$ is the Secchi depth reading, and $d$ is the depth to the bed.

Formula 1 is an established equation, appearing for example in Chapter 5 of Wetzel's general Limnology text ${ }^{1}$. Formula 2 is an estimate, and allows for the fact that growth proceeds in natural environments very well at reduced light intensities. We have assumed that the light sensitivity may be reduced by several times, and still result in good growth. A growth rate reduction formula that uses an exponent that is 5 times smaller than the light reduction exponent is used, as indicated by equation 2 .

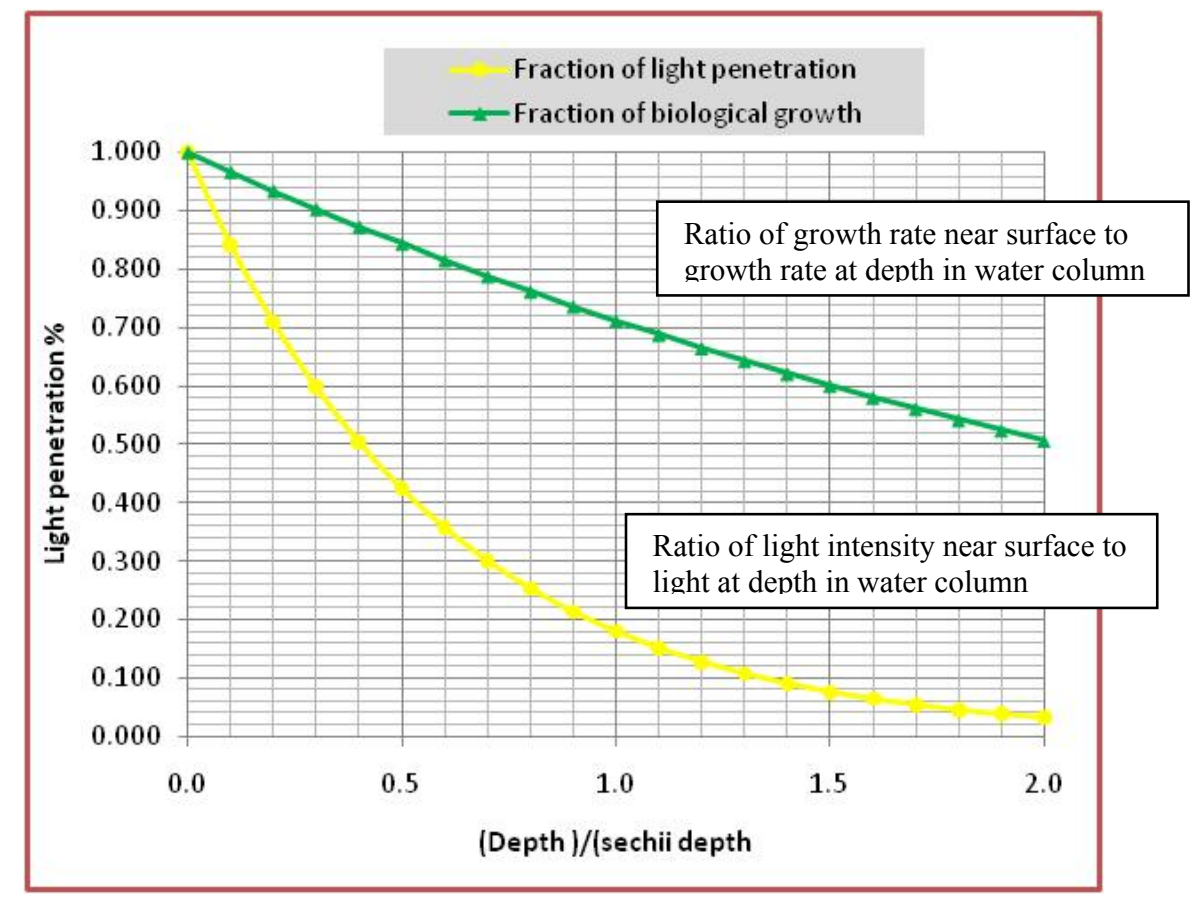

Figure 8. Relative light intensity and relative algae growth rates at the river bed.

\footnotetext{
${ }^{1}$ Wetzel R.G. Chapter 5 Light in Inland Waters of Limnology $3^{\text {rd }}$ Edition. Page 66. 
Equation 2 is preliminary, and further work will be carried out next year, to search for published results for plankton growth in reduced light.

Details of the 11 cross-sections used are presented in an earlier report by Ward \& Associates $\mathrm{Ltd}^{2}$. The effect of changing the river discharge is to alter the depth to the bed of the river, and in some cases to cause parts of the cross-section, e.g gravel bars, to be submerged or rendered high and dry. For each cross-section and each river flow rate, the relative growth rates on the river bed at each vertical spaced at about $5 \mathrm{~m}$ intervals is computed. An average growth rate for each cross section is computed, based on about 20 to 30 verticals. Results water transparencies represented by three Secchi Disk values are shown, see Table 4. These values represent the range of Secchi Disk values in the river measured in summer 2008. Low values for relative growth rates are computed for the end of May period, and high values for mid July, as the river reduced its suspended sediment load.

Table 4. Relative growth rates for three values of Secchi Depth at three river flows.

\begin{tabular}{|c|c|c|c|c|c|c|c|c|c|}
\hline For Secchi depth reading & & $3 \mathrm{~m}$ & & & $.5 \mathrm{~m}$ & & & $.0 \mathrm{~m}$ & \\
\hline \multirow{2}{*}{ Section Number } & \multicolumn{3}{|c|}{ "River Flows [kcfs] } & \multicolumn{3}{|c|}{ "River Flows [kcfs] } & \multicolumn{3}{|c|}{ "River Flows [kcfs] } \\
\hline & 30 & 25 & 20 & 30 & 25 & 20 & 30 & 25 & 20 \\
\hline 1 & $6 \%$ & $7 \%$ & $12 \%$ & $52 \%$ & $55 \%$ & $61 \%$ & $71 \%$ & $74 \%$ & $77 \%$ \\
\hline 2 & $34 \%$ & $32 \%$ & $12 \%$ & $65 \%$ & $62 \%$ & $51 \%$ & $78 \%$ & $76 \%$ & $70 \%$ \\
\hline 3 & $26 \%$ & $32 \%$ & $25 \%$ & $64 \%$ & $67 \%$ & $61 \%$ & $78 \%$ & $80 \%$ & $77 \%$ \\
\hline 4 & $1 \%$ & $1 \%$ & $1 \%$ & $30 \%$ & $32 \%$ & $35 \%$ & $54 \%$ & $56 \%$ & $59 \%$ \\
\hline $4 a$ & $27 \%$ & $39 \%$ & $44 \%$ & $71 \%$ & $77 \%$ & $79 \%$ & $84 \%$ & $87 \%$ & $88 \%$ \\
\hline 6 & $9 \%$ & $5 \%$ & $6 \%$ & $41 \%$ & $40 \%$ & $44 \%$ & $62 \%$ & $62 \%$ & $66 \%$ \\
\hline 8 & $10 \%$ & $1 \%$ & $2 \%$ & $32 \%$ & $27 \%$ & $29 \%$ & $54 \%$ & $51 \%$ & $53 \%$ \\
\hline 9 & $2 \%$ & $3 \%$ & $5 \%$ & $39 \%$ & $42 \%$ & $47 \%$ & $62 \%$ & $65 \%$ & $68 \%$ \\
\hline 10 & $6 \%$ & $9 \%$ & $14 \%$ & $46 \%$ & $50 \%$ & $56 \%$ & $66 \%$ & $69 \%$ & $73 \%$ \\
\hline 11 & $5 \%$ & $7 \%$ & $11 \%$ & $48 \%$ & $53 \%$ & $59 \%$ & $69 \%$ & $72 \%$ & $76 \%$ \\
\hline 12 & $16 \%$ & $21 \%$ & $24 \%$ & $58 \%$ & $62 \%$ & $64 \%$ & $75 \%$ & $77 \%$ & $79 \%$ \\
\hline 13 & $8 \%$ & $13 \%$ & $7 \%$ & $41 \%$ & $45 \%$ & $43 \%$ & $61 \%$ & $63 \%$ & $62 \%$ \\
\hline Average for $9 \mathrm{~km}$ & $13 \%$ & $14 \%$ & $14 \%$ & $49 \%$ & $51 \%$ & $52 \%$ & $68 \%$ & $69 \%$ & $71 \%$ \\
\hline
\end{tabular}

Transparencies at Secchi depths of $0.3 \mathrm{~m}$ were judged by the operating committee to be too small for start-up, and it was decided to wait for improved conditions in the river. Dosing work was started once the Secchi depth reached about $1.5 \mathrm{~m}$.

\section{Operation and Performance of Dosing \& Measuring System}

The system was connected up, and a new filter was installed between the pump and the Seametrics meter, prior to the June $1^{\text {st }}$ scheduled start date. However, for reasons

\footnotetext{
${ }^{2}$ Ward \& Associates Ltd. 2006. Kootenai River Nutrient Dosing System and N-P Consumption. December 2006, 23 pp.
} 
explained in the previous section, start up was delayed until turbidity values decreased in the river. Flow calibration of the Prominent Gamma/L pumps was done, and start-up was about $2 \mathrm{pm}$ on $15^{\text {th }}$ June, see Figure 9. At this time a sample of the 10-34-0 nutrient was taken, for laboratory analysis.

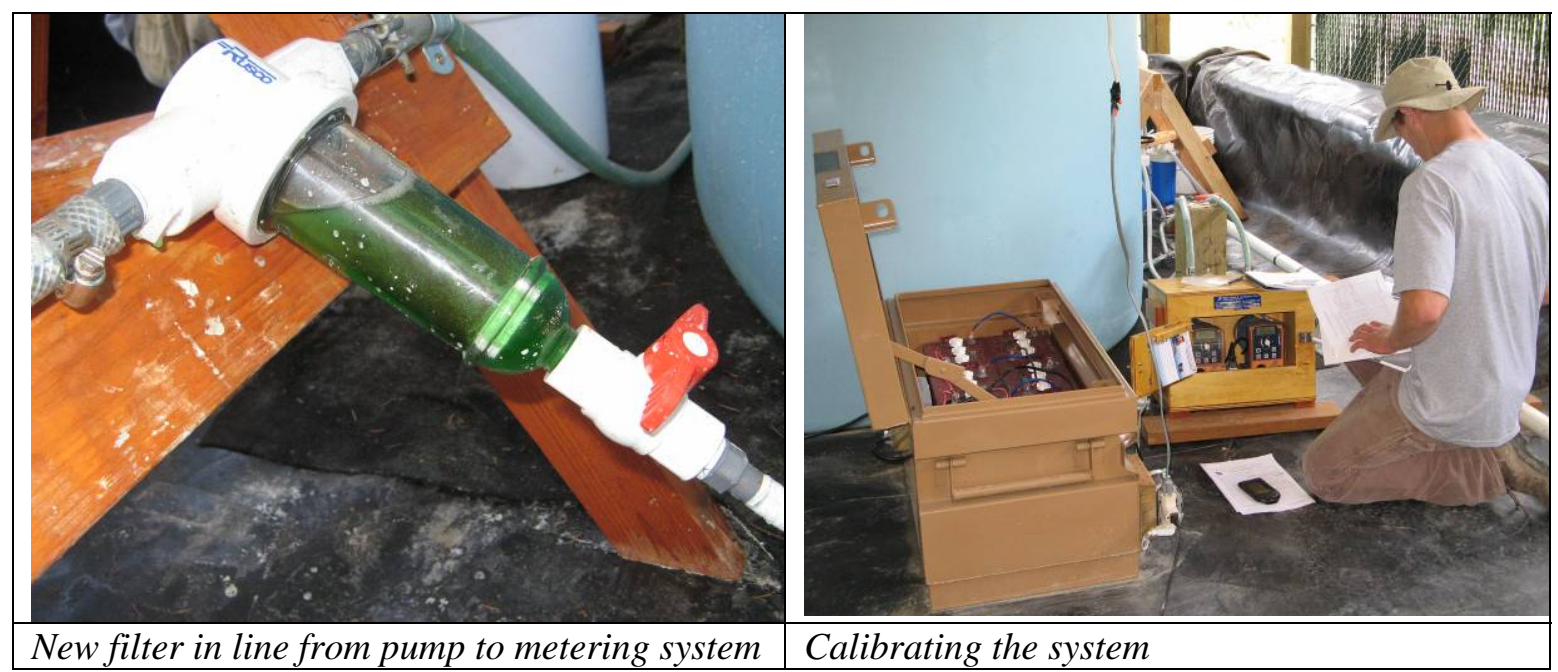

Figure 9. Start of season dosing system set-up.

A site visit was undertaken on $8^{\text {th }}$ and $9^{\text {th }}$ of July, during which the flow, as indicated by the Gamma/L display was checked and re-set, using the flow volume collected in the $1000 \mathrm{~mL}$ standard flask to determine an accurate flow rate. In addition the flow indication from the Seametrics flow gauge was read. The equipment and flow calibration procedure are shown, see Figure 10.

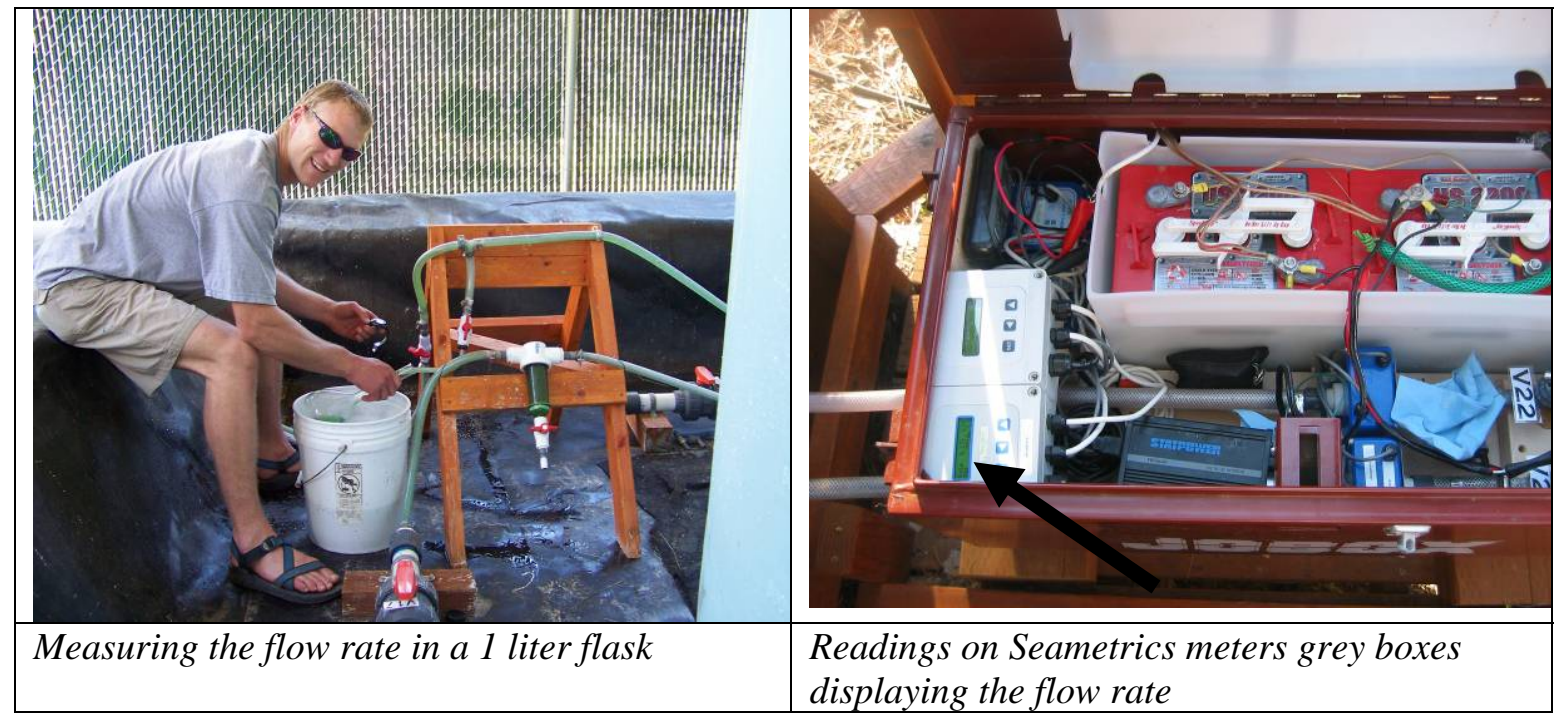

Figure 10. Flow calibration and checking of Seametrics flow instrument. 
A plot of the cumulative volume of 10-34-0 added during the season was prepared, based on the readings from the Seametrics meter. Data at 4 minute intervals were downloaded from the Seametrics data logger, and daily total volumes (midnight to midnight) were computed. These amounts were not corrected for the small error in flow rate $(2 \%$ uncertainty) from the meter, because the value was so small. Results for the $3 \frac{1}{2}$ month period $\left(15^{\text {th }}\right.$ June to $30^{\text {th }}$ September 2007) are shown, see Figure 11 (red line).

Also shown in Figure 11 is a comparison of the volume of 10-34-0 added, based on the Seametrics data logger, versus a theoretical volume that would provide $3.0 \mu \mathrm{g} / \mathrm{L}$ based on Kootenai River flows downloaded from the USGS Internet site. This theoretical volume is subject to the uncertainty present in assessing flow rates, estimated as $\pm 5 \%$, see Section 3. We assume for this calculation that the total-P content of the 10-34-0 is in agreement with the manufacturer's specification $(212.5 \mathrm{~g} / \mathrm{L})$. Note that the difference between the red line (actual amount added) and the range of values for the blue line in Figure 11 is not significant.

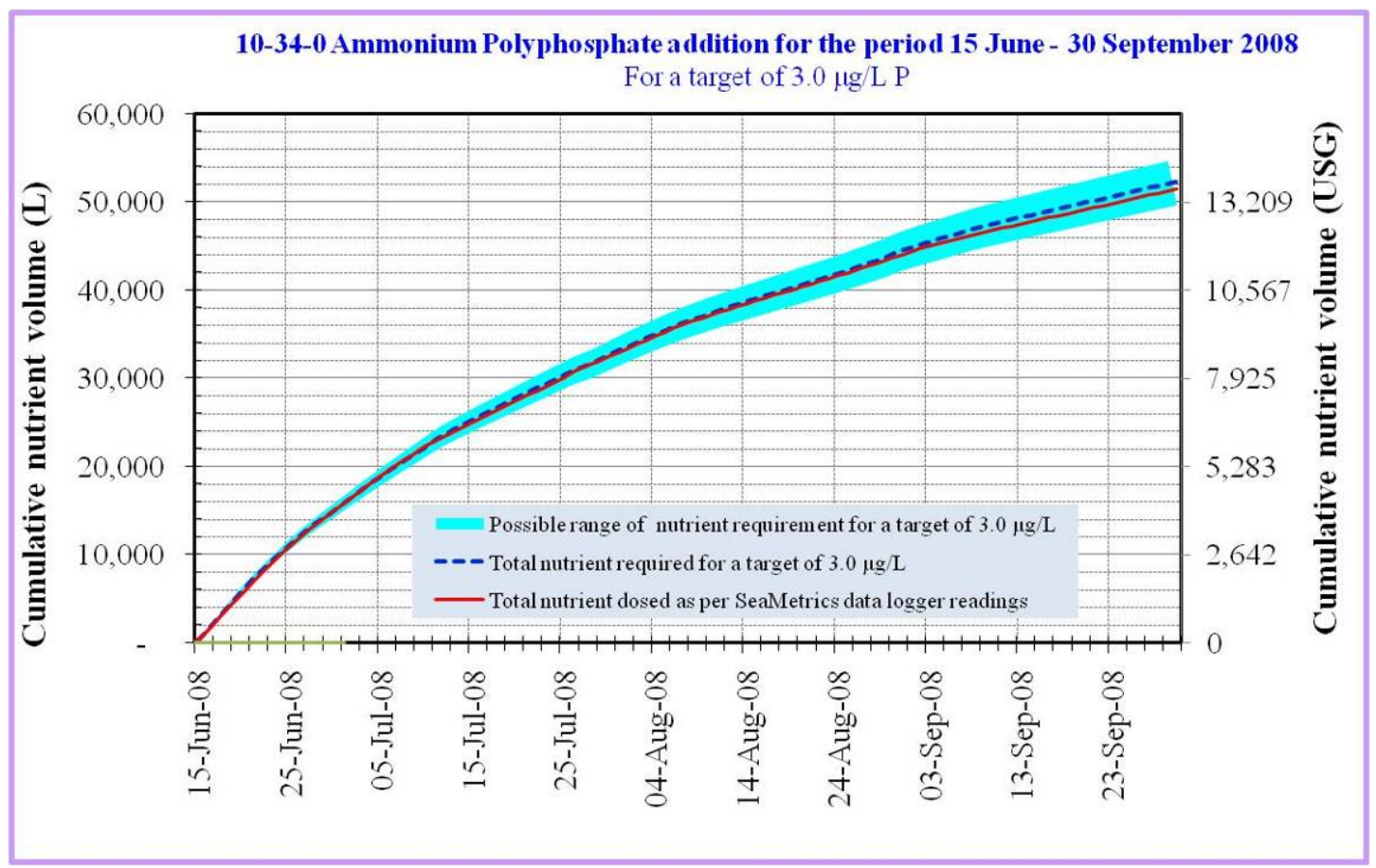

Figure 11. Comparison of volume of 10-34-0 added versus volume needed based on automated river gauge readings.

There are two main reasons why the red line does not exactly co-incide with the middle of the blue line, as follows.

- Different methods of measuring the water surface level at the Leonia gauge. The red line employed a manual method, whereby the gauge was read manually on a 
daily basis by the site technician observing the water level on the staff gauge. The technician then computed flows using the rating curve (as shown in Figure 3). The blue line employed an automated method, whereby the bubbler system at the gauge determined the water surface height from a transducer that measured back pressure on the bubbler. These data were sent by satellite transmission, and automatically transferred to flows using the rating curve.

- Operator error. The reading of the gauge and the calculation of the required dosing flow rate may have had small errors, showing up as the incorrect dosing flow rate.

Monthly reviews of the work were undertaken during the season, as part of the requirements of the USEPA licensing permit. These provided material for DMR (Discharge Monitoring Reports) for submission to the USEPA, on a monthly basis. Tabulated materials for these reports were prepared during the first week of each month during the operating season, and passed on to Idaho Fish and Game for preparation of the DMRs. The (four) tables for June, July, August and September are shown, see Appendix B.

A summary table of nutrient dosing (see Table 5) during the 2008 and 2007 seasons is shown.

Table 5.

Summary of Nutrient (10-34-0) Addition Programme for 2008 and 2007 Seasons.

\begin{tabular}{|l|c|c|}
\hline Parameter & 2008 season & 2007 season \\
\hline Time of start of nutrient addition & 15-Jun-2008 & 01 June 2007 \\
\hline Length of time nutrient added & 107 days & 122 days \\
\hline $\begin{array}{l}\text { Volume of river water passing the } \\
\text { station during the season }\end{array}$ & $3,630 \mathrm{Mm}^{3}$ & $4,750 \mathrm{Mm}^{3}$ \\
\hline $\begin{array}{l}\text { Target Phosphorus concentration after } \\
\text { complete mixing in river channel }\end{array}$ & $3.0 \mu \mathrm{g} / 1$ & $3.0 \mu \mathrm{g} / 1$ \\
\hline $\begin{array}{l}\text { Effluent (dosing flow) dilution ratio as } \\
\text { monthly averages }\end{array}$ & $\begin{array}{c}70.3 \text { to } 73.6 \mathrm{million} \\
\text { times }\end{array}$ & $\begin{array}{c}69 \text { to } 72.3 \mathrm{million} \\
\text { times }\end{array}$ \\
\hline $\begin{array}{l}\text { Total nutrient added during season } \\
13,500 \text { liters }\end{array}$ & $\begin{array}{l}67,000 \text { liters } \\
17,700 \mathrm{USG}\end{array}$ \\
\hline $\begin{array}{l}\text { Nutrient dosing controlling devices, } \\
\text { calibrated with 1.0 L standard flask }\end{array}$ & $\begin{array}{c}\text { SeaMetric flow meter } \\
\text { \& Gamma/L pump }\end{array}$ & $\begin{array}{c}\text { SeaMetric flow meter } \\
\& \text { Gamma/L pump }\end{array}$ \\
\hline $\begin{array}{l}\text { End of season difference between actual } \\
\text { volume and theoretical nutrient volume } \\
\text { (based on automated river gauge flows). }\end{array}$ & $-1.5 \%$ & $-2 \%$ \\
\hline
\end{tabular}




\section{Nitrogen Concentrations \& N-P Uptake}

Weekly samples from 2 river stations upstream, one station at the dosing site, and six stations downstream were collected and measured for nutrients as part of KTOI's nutrient project monitoring. One of the stations, near Bonner's Ferry, was much further downstream than the rest. Of particular interest were the results for nitrogen $\mathrm{N}$ (as $\mathrm{NO}_{3}+$ $\mathrm{NO}_{2}$ ). Phosphorus (TDP) concentrations were measured, but were sufficiently low that they were either undetectable, or were just above the minimum detection limit of $2 \mu \mathrm{g} / \mathrm{L}$.

It was considered important to ensure that the atomic $\mathrm{N} / \mathrm{P}$ ratio was always larger than about 15-20 times, in order to ensure minimal growth of blue-green, and other undesirable algae. Results showed that this constraint was easily complied with, for the whole season. Only in the localized area close to the diffusing plume of effluent may there have been an N/P ratio that did not reach this range. Samples for $\mathrm{N}$ were taken near the left and right banks and near the channel centre, for each station. Values were averaged for each section. (See Hoyle 2009 for more details.)

Samples during for the 14 week period 23rd June to $28^{\text {th }}$ September 2008 were collected, and 9 out of 14 possible weekly interval dates were sampled and analysed. No sampling was done in the weeks of $30^{\text {th }}$ June, $4^{\text {th }}$ August, $18^{\text {th }}$ August, $25^{\text {th }}$ August, $8^{\text {th }}$ September and $22^{\text {nd }}$ September.

Results for the summer period are shown in Figure 12. Values were higher than $100 \mu \mathrm{g} / \mathrm{L}$ for the whole summer except the $11^{\text {th }}$ August measurements. These ranged between 89 and $99 \mu \mathrm{g} / \mathrm{L}$ within the $8 \mathrm{~km}$ river treatment stretch. 


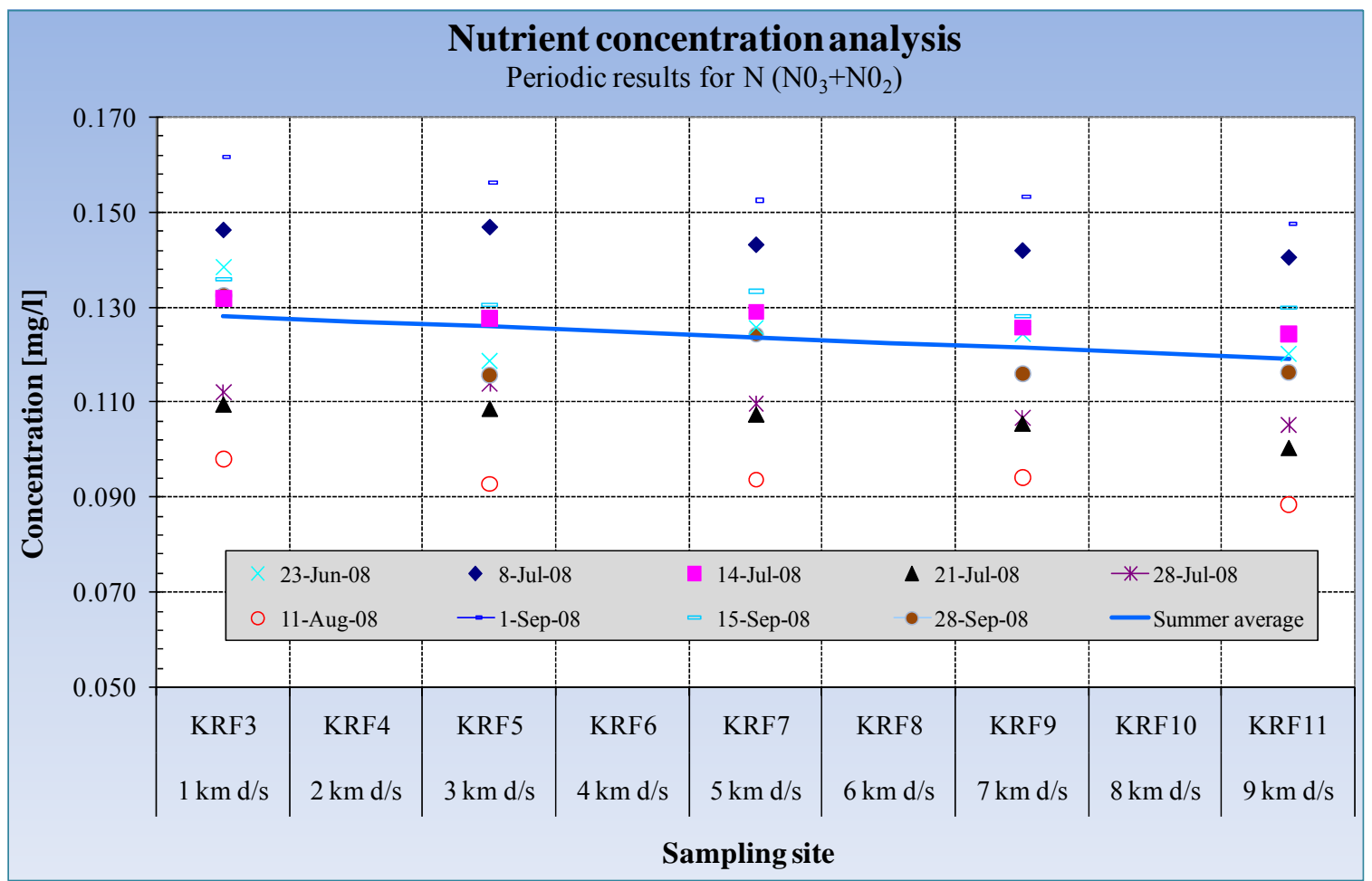

Figure 12. Weekly nitrogen $\left(\mathrm{NO}_{3}+\mathrm{NO}_{2}\right)$ concentrations for the summer 2008 period versus distance downstream from nutrient addition site.

There is a small but significant decline of $\mathrm{N}$ concentration values with distance downstream of the dosing site.

For the 2008 aquatic biomass growth period, the $\mathrm{N}\left(\right.$ as $\mathrm{NO}_{3}+\mathrm{NO}_{2}$ ) gradient, $\Delta \mathrm{C} / \Delta \mathrm{x}$, is

$\rightarrow 1.13 \mu \mathrm{g} / \mathrm{L}$ per $\mathrm{km}$ for the period

The $\mathrm{N}$ decline may also be expressed in units of $\mathrm{kg}$ /day per unit distance, by using the formula:

Rate of decline of $\mathrm{N}(\mathrm{kg} /$ day per $\mathrm{km})=0.0864 * \Delta \mathrm{C} / \Delta \mathrm{x} * \mathrm{Q}$

in which $\mathrm{Q}$ is the flow rate in the river (in $\mathrm{m}^{3} / \mathrm{s}$ )

Assuming that approximately all the decline is associated with uptake from aquatic growth, then the uptake of $\mathrm{N}$ is $(0.0864 * 1.13 * 400)=39.05 \mathrm{~kg} / \mathrm{day} / \mathrm{km}$, for an example flow of $400 \mathrm{~m}^{3} / \mathrm{s}$. 
For growth of aquatic organic matter, the N/P ratio based on atomic weights, is well established as being 16:1 (Redfield Ratio). For molecular weights of 14 (for N) and 31 (for $\mathrm{P}$ ), the ratio of actual weights of $\mathrm{N} / \mathrm{P}$ is approximately 7.23 to 1 .

Thus the uptake of $\mathrm{P}$ from aquatic growth at an example flow of $400 \mathrm{~m}^{3} / \mathrm{s}$ is equal to:

$$
39.05 / 7.23=5.40 \mathrm{~kg} / \mathrm{day} / \mathrm{km} \text { for the summer period }
$$

For the whole reach, the $\mathrm{P}$ component in the 10-34-0 that was absorbed by the river ranged in values from $116 \mathrm{~kg}$ /day in late June, to $13 \mathrm{~kg} /$ day in mid September, see Figure 13. At a target of $3 \mu \mathrm{g} / \mathrm{L} \mathrm{P}$ concentration, the amount of total $\mathrm{P}$ dosed ranged between $203 \mathrm{Kg}$ /day and $50 \mathrm{Kg}$ /day for late June and mid September example dates. Thus the fraction of the total $\mathrm{P}$ being dosed that was consumed by aquatic growth in the $8 \mathrm{~km}$ reach downstream of the dosing site ranged between $57 \%$ to $26 \%$. Figure 13 shows a detailed table with nitrogen and phosphorus uptake computations for the whole of the summer.

\begin{tabular}{|c|c|c|c|c|c|c|c|c|c|c|}
\hline & Sampling Date & 23-Jun-08 & 8-Jul-08 & 14-Jul-08 & 21-Jul-08 & 28-Jul-08 & 11-Aug-08 & 1-Sep-08 & 15-Sep-08 & 28-Sep-08 \\
\hline Daily flows (cfs) & & 27,638 & 19,630 & 14,989 & 14,370 & 11,325 & 10,118 & 9,490 & 6,769 & 6,683 \\
\hline Daily flows $\left(\mathrm{m}^{3} / \mathrm{s}\right)$ & & 783 & 556 & 424 & 407 & 321 & 287 & 269 & 192 & 189 \\
\hline \multicolumn{2}{|c|}{ Loss of $N$ in $8 \mathrm{~km}$ reach per day $[\mathrm{Kg} /$ day] } & 835 & 317 & 251 & 308 & 237 & 180 & 291 & 93 & 208 \\
\hline \multicolumn{2}{|c|}{ Rate of decline of $N$ [Kg/day per $\mathrm{km}]$} & 104 & 40 & 31 & 38 & 30 & 22 & 36 & 12 & 26 \\
\hline \multicolumn{2}{|c|}{ Loss of $N$ per km reach, $\Delta C / \Delta X[\mu \mathrm{g} / 1$ per km] } & 1.54 & 0.83 & 0.86 & 1.09 & 1.07 & 0.91 & 1.57 & 0.70 & 1.59 \\
\hline \multicolumn{2}{|c|}{ Consumed $\mathrm{P}$ at $1: 16$ mole ratio $[\mathrm{kg} /$ day per $\mathrm{km}]$} & 14.4 & 5.5 & 4.3 & 5.3 & 4.1 & 3.1 & 5.0 & 1.6 & 3.6 \\
\hline \multicolumn{2}{|c|}{ Consumed $P$ at $1: 16$ mole ratio $[\mu \mathrm{g} / 1]$} & 1.71 & 0.91 & 0.95 & 1.21 & 1.18 & 1.00 & 1.73 & 0.77 & 1.76 \\
\hline \multicolumn{2}{|c|}{ Consumed $P$ in $8 \mathrm{~km}$ reach $[\mathrm{kg} / \mathrm{day}]$} & 116 & 44 & 35 & 43 & 33 & 25 & 40 & 13 & 29 \\
\hline Dosed total P $[\mu \mathrm{g} / 1]$ & & 3.0 & 3.0 & 3.0 & 3.0 & 3.0 & 3.0 & 3.0 & 3.0 & 3.0 \\
\hline Dosed total P per day [Kg/day] & & 203 & 144 & 110 & 105 & 83 & 74 & 70 & 50 & 49 \\
\hline Fraction of dosed phosphorus c & onsumed & $57 \%$ & $30 \%$ & $32 \%$ & $40 \%$ & $39 \%$ & $33 \%$ & $58 \%$ & $26 \%$ & $59 \%$ \\
\hline
\end{tabular}

Figure 13. Nitrogen and phosphorus uptake computations in first 8 km's of treatment reach, Kootenai River, ID.

Figure 14 shows estimates of fraction of dosed phosphorus consumed based on 16:1 mole ratio of nitrogen to phosphorus for optimal biological uptake. 


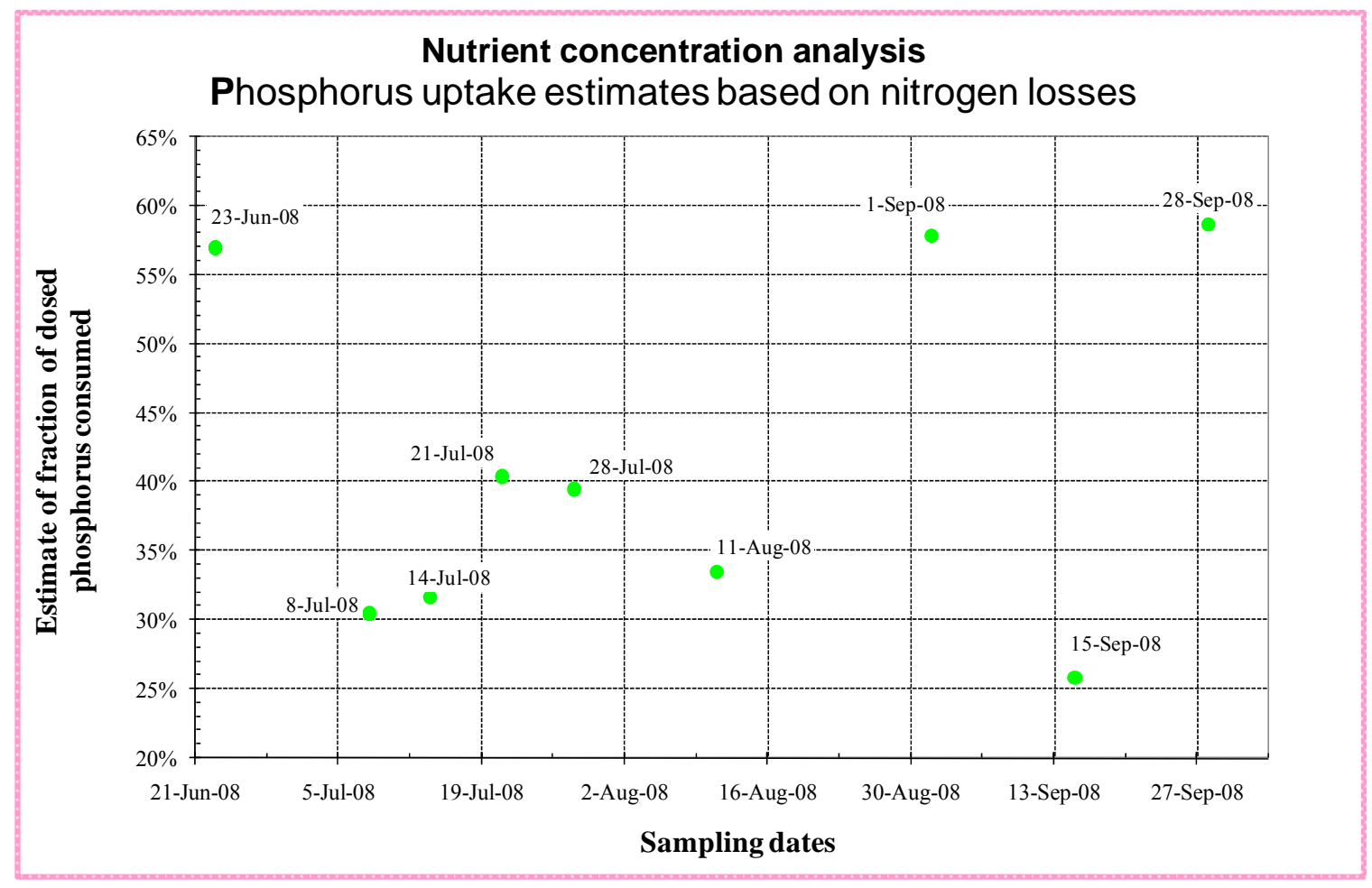

Figure 14. Phosphorus uptake estimates based on nitrogen losses in first $8 \mathrm{~km}$ of treatment reach, Kootenai River, ID.

\section{Acknowledgements:}

This work was undertaken jointly by Ward \& Associates Ltd, Kootenai Tribe of Idaho and Idaho Department of Fish and Game. A sub-committee of IKERT provided direction for the work with regular conference calls throughout the season. Support was provided by Genny Hoyle in providing water chemistry data and Sarah Richardson in collecting secchi depth measurements, both from Kootenai Tribe of Idaho office. Kirk Handley, Idaho Fish and Game, operated the nutrient addition system, and made improvements to the dosing site and facilities. The program was managed by Charlie Holderman from Kootenai Tribe of Idaho office; Ryan Hardy, Idaho Dept. Fish and Game; and Cathy Gidley, Idaho Dept. Fish and Game. The success of 2008 nutrient addition program would not have been possible without the excellent contribution of all parties. 


\section{Appendix A. Manufacturer's Data Sheet for 10-34-0 Liquid Nutrient.}

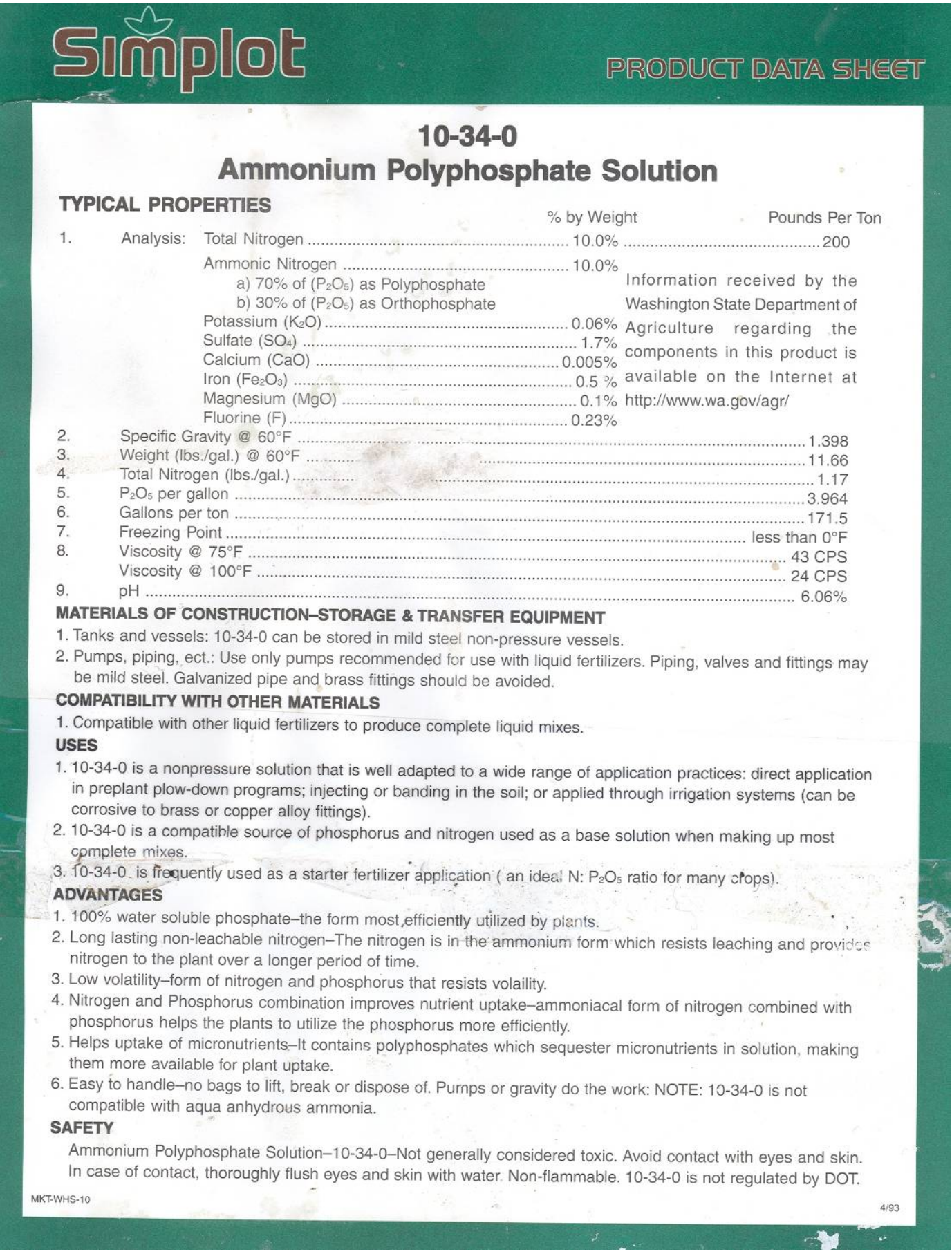




\section{Appendix B1. Monthly DMR (Discharge Monitoring Report) Sheets \& Key Pages from EPA Permit. June and July 2008:}

\begin{tabular}{|c|c|c|c|c|c|c|}
\hline \multicolumn{7}{|c|}{$\begin{array}{l}\text { Table 1: Outfall } 001 \text { Effluent Limitations and Monitoring } \\
\text { Summary for the month of June } 2008\end{array}$} \\
\hline \multicolumn{7}{|c|}{ Start up of system : $15^{\text {th }}$ June 2008 at $2: 20 \mathrm{PM}$} \\
\hline Parameter & Units & $\begin{array}{c}\text { Minimum } \\
\text { Daily } \\
\end{array}$ & $\begin{array}{l}\text { Average } \\
\text { Monthly }\end{array}$ & $\begin{array}{c}\text { Maximum } \\
\text { Daily }\end{array}$ & $\begin{array}{c}\text { Sample } \\
\text { Frequency }\end{array}$ & Sample Type \\
\hline Flow, Net $(10-34-0)^{\mathrm{a}}$ & $\mathrm{ft}^{3} /$ day & 27.2 & 34.7 & 39.8 & Daily & Measured \\
\hline Flow, Gross ${ }^{\mathrm{b}}$ & $\mathrm{ft}^{3} /$ day & 27.2 & 34.7 & 39.8 & Daily & Measured \\
\hline \begin{tabular}{|l|}
$\begin{array}{l}\text { Effluent Dilution Ratio, Net } \\
(10-34-0)^{\mathrm{a}}\end{array}$ \\
\end{tabular} & Ratio & 63.5 & 70.3 & 80.1 & & \\
\hline $\begin{array}{l}\text { Effluent Dilution Ratio, } \\
\text { Net }(10-34-0)^{\mathrm{a}}\end{array}$ & Ratio & $63,500,000: 1$ & $70,300,000: 1$ & $80,100,000: 1$ & Daily & Calculated \\
\hline $\begin{array}{l}\text { Effluent Dilution Ratio, } \\
\text { Gross }^{\text {b }}\end{array}$ & Ratio & $63,500,000: 1$ & $70,300,000: 1$ & $80,100,000: 1$ & Daily & Calculated \\
\hline Total Phosphorus as $\mathrm{P}$ & lb/day & 350 & 447 & 512 & Daily & Calculated \\
\hline Total Nitrogen & lb/day & 236 & 301 & 345 & Daily & Calculated \\
\hline Total Ammonia as N & $\mathrm{lb} /$ day & $\mathrm{N} / \mathrm{A}$ & $\mathrm{N} / \mathrm{A}$ & $\mathrm{N} / \mathrm{A}$ & $\mathrm{N} / \mathrm{A}$ & $\mathrm{N} / \mathrm{A}$ \\
\hline \multicolumn{7}{|c|}{ Notes: } \\
\hline \multicolumn{7}{|c|}{$\begin{array}{l}\text { Table 1: Outfall } 001 \text { Effluent Limitations and Monitoring } \\
\text { Summary for the month of July } 2008\end{array}$} \\
\hline Parameter & Units & $\begin{array}{c}\text { Minimum } \\
\text { Daily } \\
\end{array}$ & $\begin{array}{l}\text { Average } \\
\text { Monthly } \\
\end{array}$ & $\begin{array}{c}\text { Maximum } \\
\text { Daily } \\
\end{array}$ & $\begin{array}{c}\text { Sample } \\
\text { Frequency } \\
\end{array}$ & Sample Type \\
\hline Flow, Net $(10-34-0)^{\text {a }}$ & $\mathrm{ft}^{3} /$ day & 13.7 & 20.3 & 27.1 & Daily & Measured \\
\hline Flow, Gross ${ }^{\mathrm{b}}$ & $\mathrm{ft}^{3} /$ day & 13.7 & 20.3 & 27.1 & Daily & Measured \\
\hline $\begin{array}{l}\text { Effluent Dilution Ratio, Net } \\
(10-34-0)^{\mathrm{a}}\end{array}$ & Ratio & 46.6 & 71.1 & 89.7 & & \\
\hline $\begin{array}{l}\text { Effluent Dilution Ratio, } \\
\text { Net }(10-34-0)^{\mathrm{a}}\end{array}$ & Ratio & $46,600,000: 1$ & $71,100,000: 1$ & $89,700,000: 1$ & Daily & Calculated \\
\hline $\begin{array}{l}\text { Effluent Dilution Ratio, } \\
\text { Gross }^{\text {b }}\end{array}$ & Ratio & $46,600,000: 1$ & $71,100,000: 1$ & $89,700,000: 1$ & Daily & Calculated \\
\hline Total Phosphorus as $\mathrm{P}$ & $\mathrm{lb} /$ day & 176 & 262 & 349 & Daily & Calculated \\
\hline Total Nitrogen & lb/day & 119 & 176 & 235 & Daily & Calculated \\
\hline Total Ammonia as N & lb/day & N/A & $\mathrm{N} / \mathrm{A}$ & $\mathrm{N} / \mathrm{A}$ & N/A & N/A \\
\hline \multicolumn{7}{|c|}{$\begin{array}{l}\text { ium Polyphosphate only } \\
\text { s period, only 10-34-0 dosed }\end{array}$} \\
\hline
\end{tabular}




\section{Appendix B2. Monthly DMR (Discharge Monitoring Report) Sheets}

August and September 2008:

Table 1: Outfall 001 Effluent Limitations and Monitoring

Summary for the month of August 2008

\begin{tabular}{|c|c|c|c|c|c|c|}
\hline Parameter & Units & $\begin{array}{c}\text { Minimum } \\
\text { Daily } \\
\end{array}$ & $\begin{array}{l}\text { Average } \\
\text { Monthly } \\
\end{array}$ & $\begin{array}{c}\text { Maximum } \\
\text { Daily } \\
\end{array}$ & $\begin{array}{c}\text { Sample } \\
\text { Frequency } \\
\end{array}$ & Sample Type \\
\hline Flow, Net $(10-34-0)^{\mathrm{a}}$ & $\mathrm{ft}^{3} /$ day & 10.9 & 12.7 & 17.2 & Daily & Measured \\
\hline Flow, Gross ${ }^{\mathrm{b}}$ & $\mathrm{ft}^{3} /$ day & 10.9 & 12.7 & 17.2 & Daily & Measured \\
\hline $\begin{array}{l}\text { Effluent Dilution Ratio, Net } \\
(10-34-0)^{\mathrm{a}}\end{array}$ & Ratio & 66.0 & 71.8 & 86.4 & & \\
\hline $\begin{array}{l}\text { Effluent Dilution Ratio, } \\
\text { Net }(10-34-0)^{\mathrm{a}}\end{array}$ & Ratio & $66,000,000: 1$ & $71,800,000: 1$ & $86,400,000: 1$ & Daily & Calculated \\
\hline $\begin{array}{l}\text { Effluent Dilution Ratio, } \\
\text { Gross }^{\mathrm{b}}\end{array}$ & Ratio & $66,000,000: 1$ & $71,800,000: 1$ & $86,400,000: 1$ & Daily & Calculated \\
\hline Total Phosphorus as $\mathrm{P}$ & lb/day & 141 & 163 & 221 & Daily & Calculated \\
\hline Total Nitrogen & lb/day & 95 & 110 & 149 & Daily & Calculated \\
\hline Total Ammonia as N & lb/day & N/A & N/A & N/A & N/A & N/A \\
\hline Notes: & $\begin{array}{l}\text { a. Relate } \\
\text { b. Identic }\end{array}$ & $\begin{array}{l}\text { 10-34-0 Amm } \\
\text { to Net (a) for t }\end{array}$ & $\begin{array}{l}\text { ium Polyphosp } \\
\text { s period, only } 1\end{array}$ & $\begin{array}{l}\text { te only } \\
\text { 34-0 dosed }\end{array}$ & & \\
\hline
\end{tabular}

Table 1: Outfall 001 Effluent Limitations and Monitoring Summary for the month of September 2008

\begin{tabular}{|c|c|c|c|c|c|c|}
\hline Parameter & Units & $\begin{array}{c}\text { Minimum } \\
\text { Daily }\end{array}$ & $\begin{array}{l}\text { Average } \\
\text { Monthly }\end{array}$ & $\begin{array}{c}\text { Maximum } \\
\text { Daily }\end{array}$ & $\begin{array}{c}\text { Sample } \\
\text { Frequency }\end{array}$ & Sample Type \\
\hline Flow, Net $(10-34-0)^{\text {a }}$ & $\mathrm{ft}^{3} /$ day & 8.0 & 8.8 & 12.2 & Daily & Measured \\
\hline Flow, Gross ${ }^{\mathrm{b}}$ & $\mathrm{ft}^{3} /$ day & 8.0 & 8.8 & 12.2 & Daily & Measured \\
\hline $\begin{array}{l}\text { Effluent Dilution Ratio, } \\
\text { Net }(10-34-0)^{\mathrm{a}}\end{array}$ & Ratio & $68,300,000: 1$ & $73,600,000: 1$ & $91,100,000: 1$ & Daily & Calculated \\
\hline $\begin{array}{l}\text { Effluent Dilution Ratio, } \\
\text { Gross }^{\text {b }}\end{array}$ & Ratio & $68,300,000: 1$ & $73,600,000: 1$ & $91,100,000: 1$ & Daily & Calculated \\
\hline Total Phosphorus as $\mathrm{P}$ & $\mathrm{lb} /$ day & 102 & 113 & 157 & Daily & Calculated \\
\hline Total Nitrogen & $\mathrm{lb} /$ day & 69 & 76 & 106 & Daily & Calculated \\
\hline Total Ammonia as N & $\mathrm{lb} /$ day & N/A & N/A & N/A & N/A & N/A \\
\hline Notes: & $\begin{array}{l}\text { a. Relate } \\
\text { b. Identic }\end{array}$ & $\begin{array}{l}\text { 10-34-0 Amr } \\
\text { o Net (a) for }\end{array}$ & $\begin{array}{l}\text { um Polyphos } \\
\text { period, only }\end{array}$ & $\begin{array}{l}\text { te only } \\
34-0 \text { dosed }\end{array}$ & & \\
\hline
\end{tabular}




\title{
Key Pages from EPA Permit
}

\section{\&EPA}

\section{Fact Sheet}

Public Comment Start Date:

April 13, 2006

Public Comment Expiration Date: May 15, 2006

\author{
Technical Contact: Brian Nickel \\ 206-553-6251 \\ 800-424-4372, ext. 6251 (within Alaska, Idaho, Oregon and Washington) \\ Nickel.Brian@epa.gov
}

Proposed Issuance of a National Pollutant Discharge Elimination System (NPDES) Permit to Discharge Pollutants Pursuant to the Provisions of the Clean Water Act (CWA)

\section{Idaho Department of Fish and Game Kootenai River Nutrient Injection Site}

EPA Proposes To Issue an NPDES Permit

EPA proposes to issue an NPDES permit for the facility referenced above. The draft permit places conditions on the discharge of pollutants from the wastewater treatment plant to waters of the United States. In order to ensure protection of water quality and human health, the permit places limits on the types and amounts of pollutants that can be discharged from the facility.

This Fact Sheet includes:

- information on public comment, public hearing, and appeal procedures

- a listing of proposed effluent limitations and other conditions for the facility

- a map and description of the discharge location

- technical material supporting the conditions in the permit

\section{Certification}

EPA is requesting that the Idaho Department of Environmental Quality (IDEQ) certify the NPDES permit for this facility, under Section 401 of the Clean Water Act. Comments regarding the certification should be directed to:

Idaho Department of Environmental Quality

2110 Ironwood Parkwav 
R3-73-033) can be used to determine numeric criteria for the protection of the agricultural water supply use.

\section{Effluent Limitations}

\section{A. Basis for Effluent Limitations}

In general, the CWA requires that the effluent limits for a particular pollutant be the more stringent of either technology-based limits or water quality-based limits. Technology-based limits are set according to the level of treatment that is achievable using available technology. A water quality-based effluent limit is designed to ensure that the water quality standards applicable to a waterbody are being met and may be more stringent than technology-based effluent limits. The basis for the effluent limits proposed in the draft permit is provided in Appendix D.

\section{B. Proposed Effluent Limitations}

Below are the proposed effluent limits that are in the draft permit.

1. The permittee must not discharge excess nutrients in amounts that can cause visible slime growths or other nuisance aquatic growths impairing designated beneficial uses of the receiving water (see IDAPA 58.01.02.200.06).

\begin{tabular}{||l|l|l||}
\hline \multicolumn{3}{|c|}{ Table 1: Proposed Effluent Limits } \\
\hline \hline Parameter & Units & Minimum Monthly Average Limit \\
\hline \hline Effluent Dilution Ratio, Net, 10-34-0 & Ratio & $53,000,000: 1$ \\
\hline \hline
\end{tabular}

\section{Monitoring Requirements}

\section{A. Basis for Effluent and Surface Water Monitoring}

Section 308 of the CWA and federal regulation 40 CFR 122.44(i) require monitoring in permits to determine compliance with effluent limitations. Monitoring may also be required to gather effluent and surface water data to determine if additional effluent limitations are required and/or to monitor effluent impacts on receiving water quality.

The permittee is responsible for conducting the monitoring and for reporting results on Discharge Monitoring Reports (DMRs) or on the application for renewal, as appropriate, to the U.S. Environmental Protection Agency (EPA).

\section{B. Effluent Monitoring}

Monitoring frequencies are based on the nature and effect of the pollutant, as well as a determination of the minimum sampling necessary to adequately monitor the facility's performance. Permittees have the option of taking more frequent samples than are required under the permit. Table 2, below, presents the proposed effluent monitoring requirements. If no discharge occurs during the reporting period, "no discharge" shall be reported on the DMR. 